\title{
Protein profiles of bacteriophages of the family Myoviridae-like induced on $M$. haemolytica
}

\author{
Renata Urban-Chmiel ${ }^{1 *} \mathbb{D}$, Andrzej Wernicki ${ }^{1}$, Jacek Wawrzykowski ${ }^{2}$, Andrzej Puchalski ${ }^{1}$, Anna Nowaczek', \\ Marta Dec ${ }^{1}$, Diana Stęgierska ${ }^{1}$ and Mohammed Mijbas Mohammed Alomari ${ }^{1,3}$
}

\begin{abstract}
The aim of study was to isolate, characterize and analyse the protein profiles of Myoviridae-like bacteriophages obtained from M. haemolytica using MALDI TOF mass spectrometry. The material consisted of the M. haemolytica reference strain $A T C C^{\circledR}$ BAA410, reference serotypes $A 1, A 2, A 5, A 6, A 7, A 9$, and $A 11$, and wild-type isolates of serotype $A 1$. Bacteriophage morphology was examined with a transmission electron microscope. The proteins were separated in SDS-PAGE and two-dimensional electrophoresis and characterized by MALDI-TOF. Among the phages obtained, seven were specific for strains A1, A2, A5, A6, A7 and 25, and PHL-1 was specific for the BAA410 strain. The protein profiles for the phages were very similar to one another, but differed from the reference phage in that they lacked protein fractions with molecular weights of 22.9, 56.3 and $73.1 \mathrm{kDa}$. 2D electrophoresis revealed significant differences in the size of proteins and their localization in the $\mathrm{pH}$ gradient. The most similar profiles were observed in phages specific for strains BAA-410 and A6. In all profiles two main spots were observed in the molecular weight range from 44 to $70 \mathrm{kDa}$ at $\mathrm{pH}<4$. The results indicate that $2 \mathrm{D}$ electrophoresis is a very useful tool for characterization of phage protein profiles. An important objective was to determine the molecular differences between morphologically similar phages belonging to one family and to find similarities to phages specific for other pathogens. The study also assessed the suitability of the methods used to characterize phages.
\end{abstract}

Keywords: Bacteriophages, M. haemolytica, SDS-PAGE, Two-dimensional electrophoresis, Mass spectrometry

\section{Introduction}

All types of bacteria exhibit susceptibility to bacteriophages specific to them. Numerous studies have shown that bacteriophages can be isolated from a variety of environments in which bacteria are present. Examples include natural water bodies, wastewater, soil, plants and animals (Kutateladze and Adamia 2010; Leverentz et al. 2004).

Bacteriophages, apart from genetic material consisting of nucleic acid (RNA or DNA), are composed of a protein coat forming the structure of the phage. Traditional

\footnotetext{
*Correspondence: renata.urban@up.lublin.pl

1 Sub-department of Veterinary Prevention and Avian Diseases, Institute of Biological Bases of Animal Diseases, Faculty of Veterinary Medicine, University of Life Sciences, 20-033 Lublin, Poland

Full list of author information is available at the end of the article
}

methods for identifying bacteriophages make it possible to determine the family they belong to on the basis of their morphological structure, as well as their range of lytic activity. Restriction analysis of the genetic material of phages can be used to classify them to species and evaluate relatedness within the species, family and group. In some cases (Zhang et al. 2006), comprehensive restriction analysis is not possible because identical restriction profiles are obtained for phages belonging to the same or different families. Numerous studies (Bovet et al. 1990; Ngwai et al. 2005) have confirmed that detailed analysis of protein profiles may be a useful element in differentiating even bacteriophages belonging to the same family.

Molecular methods such as polyacrylamide gel electrophoresis (SDS PAGE) are able to determine the molecular weights of phage proteins, enabling detection of individual protein molecules during identification of viruses 
and bacteria isolated from different environments (Zimmer et al. 2002). The use of SDS-PAGE in many studies has enabled detection and detailed analysis of the protein profiles of phages specific for E. coli and S. aureus (Ngwai et al. 2005; Elshayeb et al. 2011).

According to Barrangou et al. (2002), even in bacteriophages belonging to the same family there may be differences in the presence of structural proteins, which are unique to each phage and depend on its morphology. It has been suggested that the pattern of expression of individual structural proteins of phages could be used for morphotyping and differentiation of individual phages even within the same family. Differences in the occurrence of particular proteins in bacteriophages may affect their lytic functions, titre stability and other, as yet unknown life functions. In view of the above, the aim of the present study was the isolation and electrophoretic characterization of protein profiles of phages obtained from M. haemolytica.

\section{Materials and methods}

\section{Bacterial strains}

The material consisted of the reference strain M. haemolytica serotype 1 (ATCC $^{\circledR}$, American Type Culture Collection) BAA- $410^{\mathrm{TM}}$, reference serotypes A1 (P588), A2 (499), A5 (P501), A6 (6174), A7, A9 and A11, and wild type isolates of $M$. haemolytica obtained from cattle: 25 , 99, 101 and 1480. The wild-type strains were obtained from our own collection, isolated from cattle with clinical symptoms of BRDC (bovine respiratory disease complex). For collection of $M$. haemolytica strains from cattle the authors obtained the consent of the Second Local Ethics Committee for Animal Experiments in Lublin (Approval Number 39/2009, 09 June 2009).

The full genomic sequence of $\mathrm{PH} 2 \mathrm{M}$. haemolytica phage was presented in publication of Highlander et al. (2006). A similar GenBank accession numbers of $M$. haemolytica reference phages have been avaiable also in references Niu et al. (2015).

Bacteria were stored at $85{ }^{\circ} \mathrm{C}$ in $50 \%(\mathrm{v} / \mathrm{v})$ glycerol in brain heart infusion broth (BHIB; Sigma). Isolates were plated on blood agar (BHIA) containing $5 \%(\mathrm{v} / \mathrm{v})$ sheep's blood and incubated overnight at $37{ }^{\circ} \mathrm{C}$. The starter cultures were prepared by inoculating a few colonies from the agar plates into $25-\mathrm{mL}$ volumes of BHIB and incubating them overnight at $37{ }^{\circ} \mathrm{C}$ with shaking at 120 r.p.m (Davies and Lee 2006).

\section{Isolation of bacteriophages}

Isolation of bacteriophages was carried out according to Davies and Lee (2006). Briefly, 20-mL volumes of BHIB in 100-mL Erlenmeyer flasks were inoculated with $0.2 \mathrm{~mL}$ of an overnight bacterial culture of each isolate of $M$. haemolytica and incubated at $37{ }^{\circ} \mathrm{C}$ with shaking at $120 \mathrm{rpm}$. After $4 \mathrm{~h}$ of incubation (logarithmic growth phase of bacteria), mitomycin C (Sigma, Ge) was added to a final concentration of $0.3 \mathrm{mg} / \mathrm{mL}$ and incubation was continued for a further $12 \mathrm{~h}$. The induction of phages (bacterial cell lysis) was monitored by measuring the optical density (OD $660 \mathrm{~nm}$ ) after the addition of mitomycin $\mathrm{C}$ and comparing it to control bacteria cultures without mitomycin. The phage-rich broth was centrifuged at $3.00 \times g$ for $20 \mathrm{~min}$ at $4{ }^{\circ} \mathrm{C}$ and filtered through $0.45 \mathrm{~mm}$ Millipore filters. Lytic properties were determined by the double layer plate method according to Huff et al. (2002).

\section{Electron microscopy analysis}

Bacteriophage morphology was examined with a transmission electron microscope using negative-stained slides with 5\% uranyl acetate solution (Xie et al. 2005). The slides were examined with a Zeiss LEO 902 electron microscope at an acceleration voltage of $80 \mathrm{kV}$ and a magnification range of 20,000-250,000.

\section{Preparation of protein extracts of bacteriophages}

The $0.5 \mathrm{~mL}$ suspension of bacteriophages was treated with $96 \% \mathrm{EtOH}$ and incubated for $24 \mathrm{~h}$ at $-20{ }^{\circ} \mathrm{C}$. Following removal of the ethanol layer, the precipitated protein was resuspended in $100 \mu \mathrm{l}$ of single-strength SDS-PAGE sample lysis buffer $(62.5 \mathrm{mM}$ Tris-HCl, $2 \%$ SDS, 6\% 2-mercaptoethanol, 10\% glycerol, 0.1\% bromophenol blue, $\mathrm{pH}$ 6.8) and heated at $100{ }^{\circ} \mathrm{C}$ for $10 \mathrm{~min}$. Protein concentration was determined by Bradford's reagent (Sigma-Aldrich, Ge).

\section{Sodium dodecyl sulphate polyacrylamide gel electrophoresis (SDS-PAGE)}

SDS-PAGE electrophoresis was performed according to Laemmli (1970). Separation was carried out in 10\% resolving gel (Tris- $\mathrm{HCl}$ buffer with $\mathrm{pH} 8.8$ ), and $4 \%$ polyacrylamide in Tris- $\mathrm{HCl}$ buffer with $\mathrm{pH} 6.8$ was used as a stacking gel. Electrophoresis was carried out in standard Tris-glycine chamber buffer at a constant current of $100 \mathrm{~mA}$. A molecular weight standard (Perfect TM Color Protein Ladder, EurX, PL) with a molecular weight range from 7 to $240 \mathrm{kDa}$ was used in the electrophoretic separation, after which the gels were stained with Coomassie blue (Sigma, $\mathrm{Ge}$ ). The stained electropherograms were analysed with a densitometer in Quantity One software (BioRad, Ge).

\section{Two-dimensional protein analysis (2D electrophoresis)} Immediately before 2D-PAGE analysis, $50 \mu \mathrm{g}$ of protein from the samples was dissolved in $125 \mu \mathrm{L}$ of buffer containing $7 \mathrm{M}$ urea, $2 \mathrm{M}$ thiourea, $4 \%$ CHAPS and $30 \mathrm{mM}$ TRIS (pH 8.8). 
All samples contained $50 \mu \mathrm{g}$ of protein each were placed on $11 \mathrm{~cm}$ IPG strips with a linear $\mathrm{pH}$ range of $3-10$. The strips were covered with mineral oil and active rehydration was carried out at $50 \mathrm{~V}$ for $12 \mathrm{~h}$ at $15{ }^{\circ} \mathrm{C}$. Focusing began at $500 \mathrm{~V}$ for $30 \mathrm{~min}$, continued at $1000 \mathrm{~V}$ for $30 \mathrm{~min}$ and was completed at $5000 \mathrm{~V}$ until a total value of $4.5 \mathrm{kVh}$ was attained. Focusing was performed in a PROTEAN ${ }^{\circledR} \mathrm{i} 12^{\mathrm{TM}}$ IEF System (Bio-RAD, USA).

After focusing the strips were equilibrated in reducing buffer (100 mM dithiothreitol; DTT, $6 \mathrm{M}$ urea, 30\% v/v glycerol, $2 \%$ SDS, pH 8.8) twice for 10 min each time, and then in alkylating buffer (150 mM IAA, $6 \mathrm{M}$ urea, 30\% $\mathrm{v} / \mathrm{v}$ glycerol, 2\% SDS) twice for $10 \mathrm{~min}$ each time at room temp. Second-dimension separation was carried out in a PROTEAN ${ }^{\circledR}$ II xi Cell (Bio-RAD, Warsaw) in $12.5 \%$ polyacrylamide gel at a constant current of $25 \mathrm{~mA} /$ gel for $6 \mathrm{~h}$ at $15^{\circ} \mathrm{C}$ (O'Farrell 1975).

Statistical analysis of the 2D electropherograms obtained was performed in ImageMaster 2D Platinum 7.0 software (USA).

\section{Ultraflex III MALDI TOF/TOF identification of selected common protein spots}

Selected spots of interest were excised from the gels, chopped into pieces, and transferred into $0.5 \mathrm{~mL}$ tubes. The gel pieces were washed 3 times with $100 \mu \mathrm{L}$ of $100 \mathrm{mM} \mathrm{NH} \mathrm{HCO}_{3}$ buffer (pH 8.5) (Sigma, Poznań, Poland) for $5 \mathrm{~min}$. Subsequently, the gel pieces were dehydrated by adding $100 \mu \mathrm{L}$ ACN and dried in a CentriVap (Labconco, local seller A.G.A Analitical, Warsaw, Poland) (room temperature, $15 \mathrm{~min}$ ) and allowed to reswell in $100 \mu \mathrm{L}$ of $10 \mathrm{mM}$ DTT in $50 \mathrm{mM} \mathrm{NH}_{4} \mathrm{HCO}_{3}$ buffer for the purpose of reduction $\left(56^{\circ} \mathrm{C}, 60 \mathrm{~min}\right)$. After cooling to room temperature, the solution was replaced by $100 \mu \mathrm{L}$ of $50 \mathrm{mM}$ iodoacetamide in $50 \mathrm{mM} \mathrm{NH}_{4} \mathrm{HCO}_{3}$ buffer and the gel pieces were incubated in the dark for $45 \mathrm{~min}$ at room temperature. The gel pieces were washed three times with $100 \mathrm{~mL}$ of $100 \mathrm{mM} \mathrm{NH}_{4} \mathrm{HCO}_{3}$ buffer for $5 \mathrm{~min}$ at room temperature, dehydrated with $100 \mu \mathrm{L}$ ACN, and dried in the CentriVap (Labconco, local seller A.G.A Analytical, Warsaw, Poland) for $15 \mathrm{~min}$.

Enzymatic digestion of the proteins was carried out on ice by stepwise addition of $10 \mu \mathrm{L}$ of $12.5 \mathrm{ng} / \mathrm{mL}$ trypsin (Trypsin Gold, mass spectrometry grade, Promega, Madison, USA) in $50 \mathrm{mM} \mathrm{NH} \mathrm{HCO}_{3}$ buffer until they were completely rehydrated. Finally, $30 \mu \mathrm{L}$ of $50 \mathrm{mM}$ $\mathrm{NH}_{4} \mathrm{HCO}_{3}$ buffer was added to keep the gel pieces covered during digestion at $37{ }^{\circ} \mathrm{C}$ overnight. After digestion, the supernatant was collected and the peptides were extracted three times with $50 \mu \mathrm{L}$ of $70 \% \mathrm{ACN}$ with $1.5 \%$ TFA by sonification for $15 \mathrm{~min}$ at room temperature in an ultrasonic water bath (Ultron U-507, Ultron, Dywity, Poland) The supernatant was collected and dried in the
CentriVap (Labconco, local seller A.G.A Analytical, Warsaw, Poland) for $45 \mathrm{~min}$ at $40^{\circ} \mathrm{C}$.

The peptide pellet was suspended in $10 \mu \mathrm{L}$ of $0.1 \%$ TFA and purified with $\mu$ C18 ZipTip (Eppendorf, Poznań, Poland) according to the manufacturer's instructions. A $1 \mu \mathrm{L}$ volume of the purified peptide mixture was placed on a pre-spotted HCCA-PAC (with 3.5-dimethoxy4-hydroxycinnamic acid) frame (Bruker, Poznań, Poland) and allowed to dry in room temperature. Mass spectra were acquired with an Ultraflex III MALDI TOF/TOF spectrometer (Bruker, Poznań, Poland). Acquisition was performed in positive ion reflector mode with a $25-\mathrm{kV}$ acceleration voltage. Flex analysis 3.0 software (BrukerDaltonics) was used to select the monoisotopic peptide masses. Peptides and proteins from mass spectrometry data were identified using the MASCOT algorithm (Mascot 2.2 software, Matrix Science Ltd, London, United Kingdom) interrogating the Swiss-Prot database (UniProt release 2016_08) restricted to human taxonomy. Search parameters were set as follows: enzyme-trypsin, modification obligatory-carbamidomethylation cysteine, possible modification-oxidation of methionine, error of 50 ppm (Webster and Oxley 2005).

\section{Results \\ Morphology of bacteriophages}

Among the bacteriophages obtained, seven phages specific for strains A1, A2, A5, A6, A7 and 25 and the reference phage PHL-2 obtained from $M$. haemolytica strain ATCC BAA-410 were set apart for comparative analysis of protein profiles. All bacteriophages subjected to electrophoretic analysis were identified as belonging to the family Siphoviridae or Myoviridae in the order Caudovirales on the basis of their morphological structure. However, only Myoviridae-like phages were used for the comparative analysis (Fig. 1).

The bacteriophages chosen for electrophoretic analysis exhibited significant morphological similarity and had lysogenic properties characterized by the formation of cloudy plaques in the form of ring-shaped zones of bacterial growth inhibition on double-layer plates with BHI agar (Fig. 2).

\section{SDS-PAGE and proteomic results}

Analysis of the electrophoregrams in SDS-PAGE electrophoresis revealed the presence of two main protein fractions with molecular weights of 39.8 and $34.8 \mathrm{kDa}$ in all the phage profiles analysed Fig. 3. Moreover, in all profiles a band with a molecular weight of $25.8 \mathrm{kDa}$ was present. The protein profiles obtained for phages A1, A2, A5, A6 and A7 were very similar to one another, but differed from the reference phage in that they lacked protein fractions with molecular weights of 22.9, 56.3 


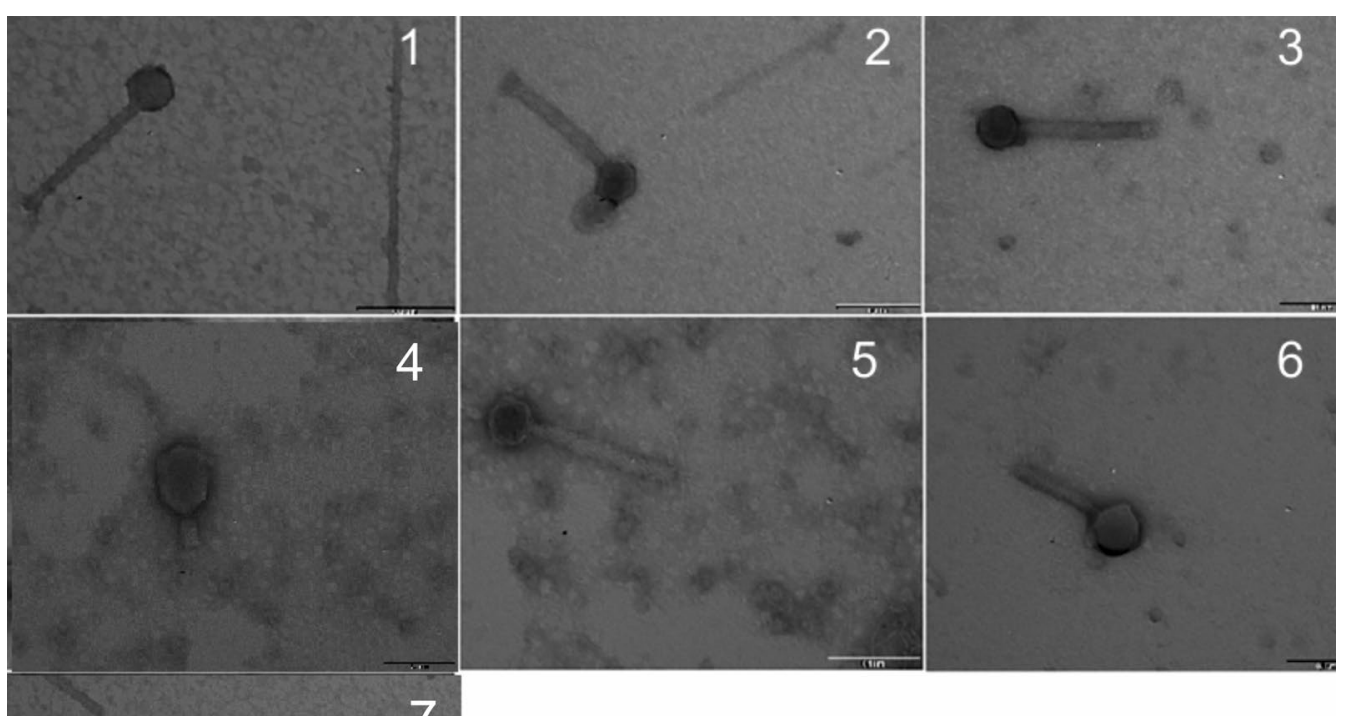

Fig. 1 Negative-stained electron micrographs of phages induced in isolates of $M$. haemolytica Myoviridae-type phage. 1-phage induced from $M$.

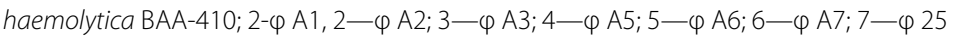

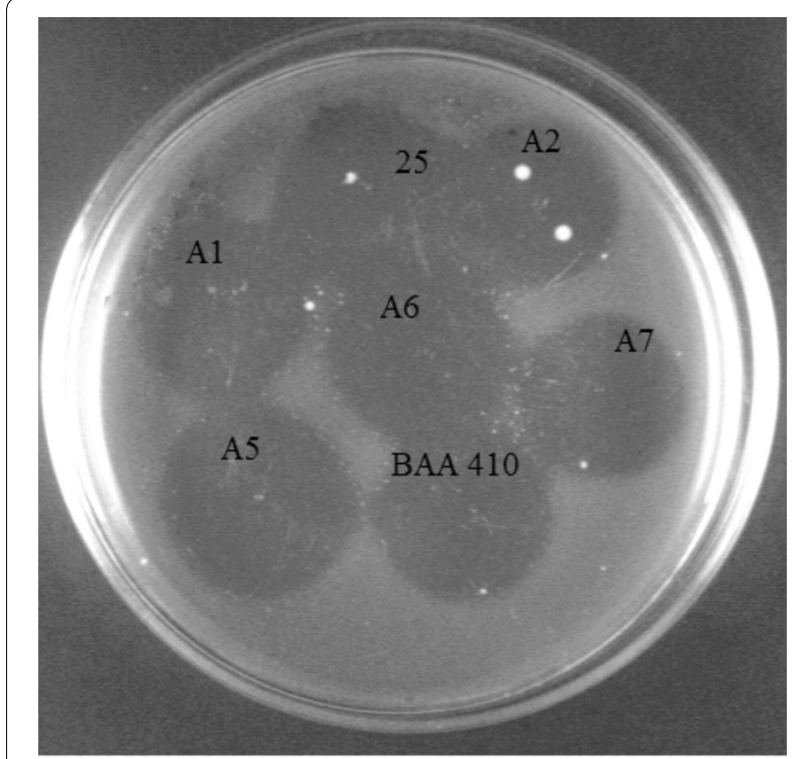

Fig. 2 Lytic zones (plaques) of the lysogenic Myoviridae phages specific for M. haemolytica strains and $73.13 \mathrm{kDa}$, which were observed in phage PHL-2. In the case of the phage obtained from M. haemolytica field strain no. 25 belonging to serotype 1 , the protein profile exhibited low similarity to the reference phage PHL-2 like, induced from $M$. haemolytica strain BAA410 (Fig. 3).

Analysis of the electrophoregrams in 2D electrophoresis revealed significant differences in the size of proteins and their localization in the $\mathrm{pH}$ gradient. The most similar protein profiles were observed in the case of phages from strains BAA-410 and A6 Fig. 4. The phages induced from strains A2 and A7 were also very similar. In all profiles the occurrence of two main spots was observed with a molecular weight range from 44 to $70 \mathrm{kDa}$ at $\mathrm{pH}<4$. Most of the protein spots were in the molecular weight range from 31 to $69 \mathrm{kDa}$. Statistical analysis of the degree of similarity of the protein profiles (Image Master 2D Platinum 7.0) with the phage obtained from strain BAA-410 showed the highest similarity in the case of 


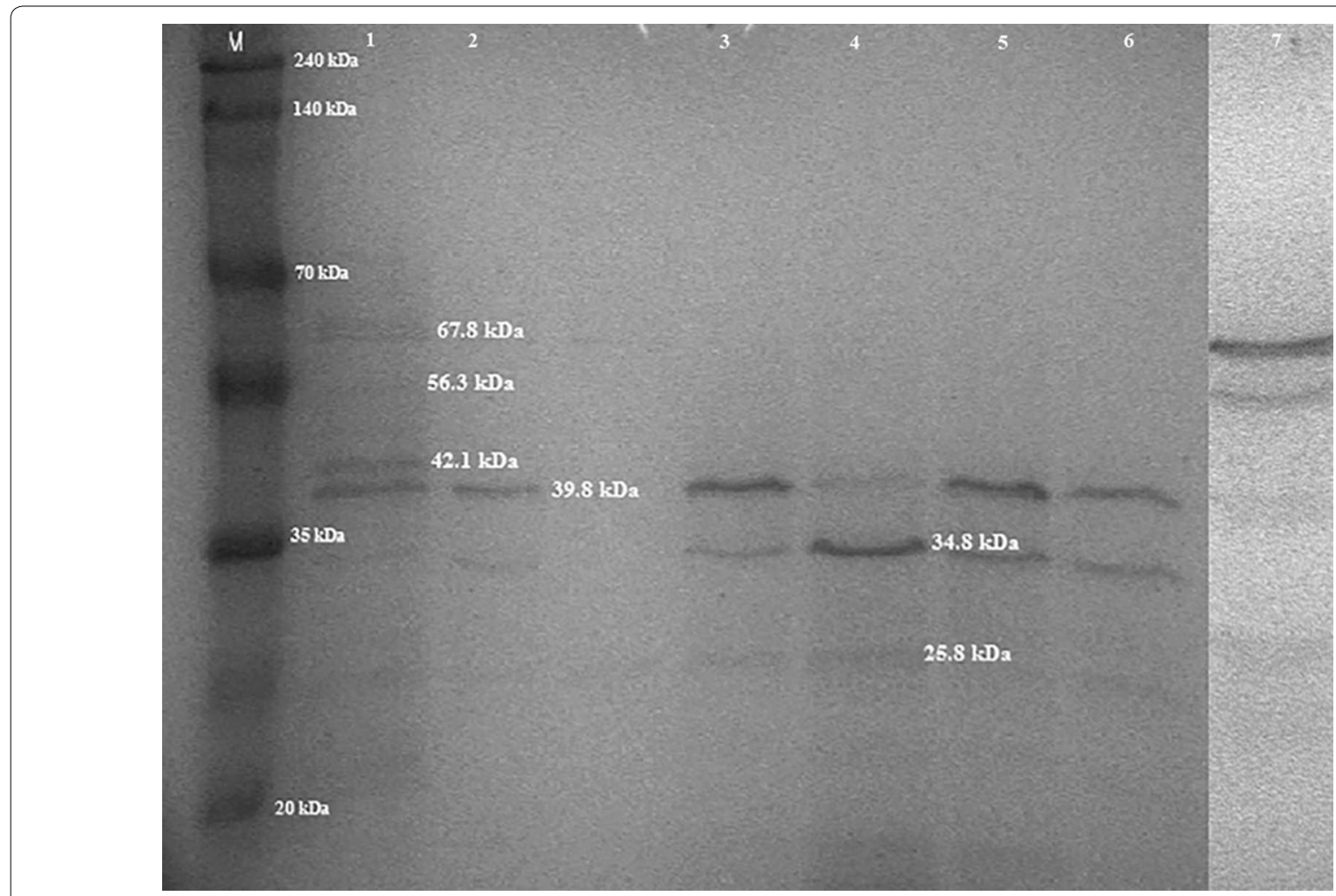

Fig. 3 Electrophoretic profiles (SDS-PAGE) of phages of the family Myoviridae specific for M. haemolytica. M-Perfect ${ }^{\mathrm{TM}}$ ColorProtein Ladder, EurX, with a mass range from 7 to $240 \mathrm{kDa}$, Line 1-phage induced from M. haemolytica BAA-410; Line 2- $\varphi$ A1, 2- $\varphi$ A2; Line 3- $\varphi$ A3; Line 4- $\varphi$ A5; Line 5- $\varphi$ A6; Line 6- 9 A7; Line 7- 225

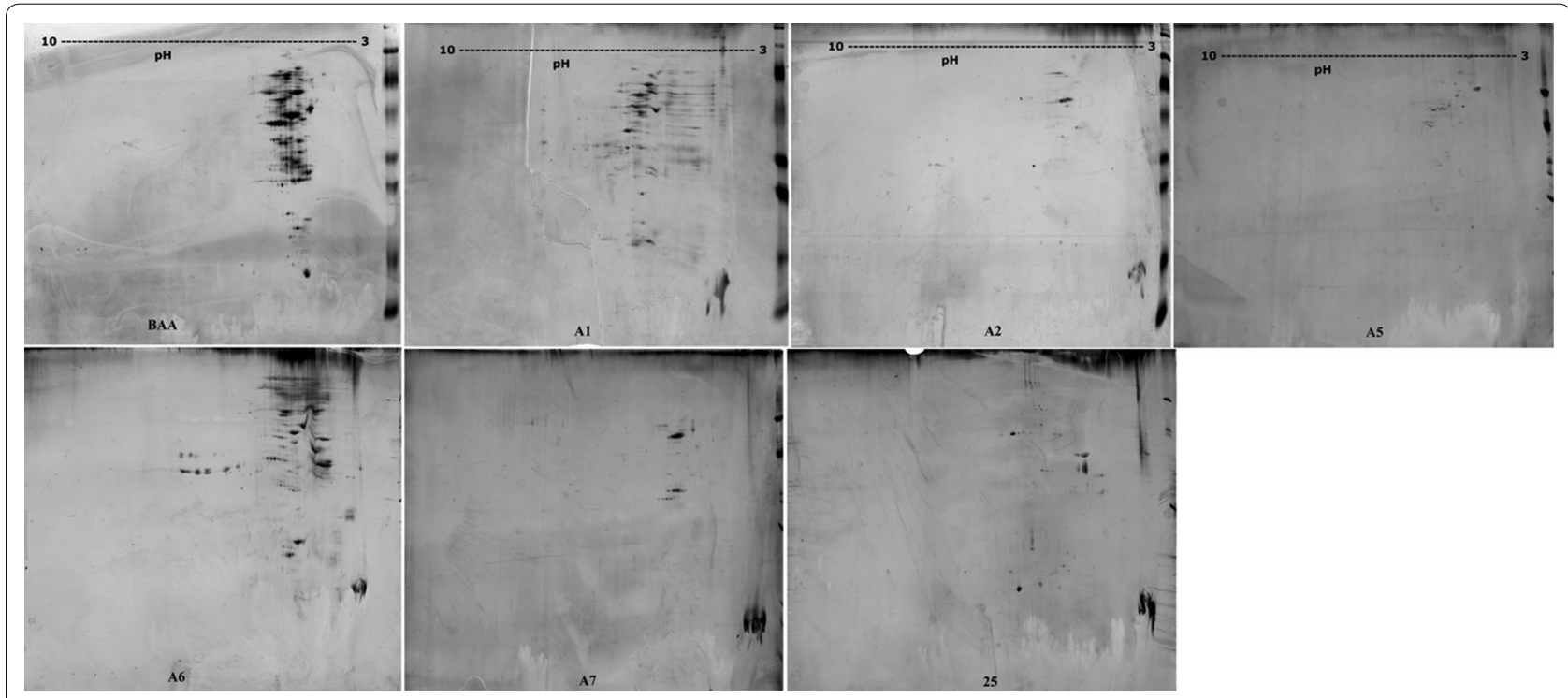

Fig. 4 Protein profiles in 2D electrophoretic images from bacteriophages specific for M. haemolytica serotype ATCC BAA-410, reference serotypes A1 (P588), A2 (499), A5 (P501), A6 (6174) and A7, and field strain 25 obtained from calves with respiratory syndrome; M-Mol. Weight. Standard 2D (No. Cat. 161-0320, BioRad, USA) 
the protein profiles of phages induced on strains A6 and BAA-410 and also strains A2 and 25 (Fig. 4).

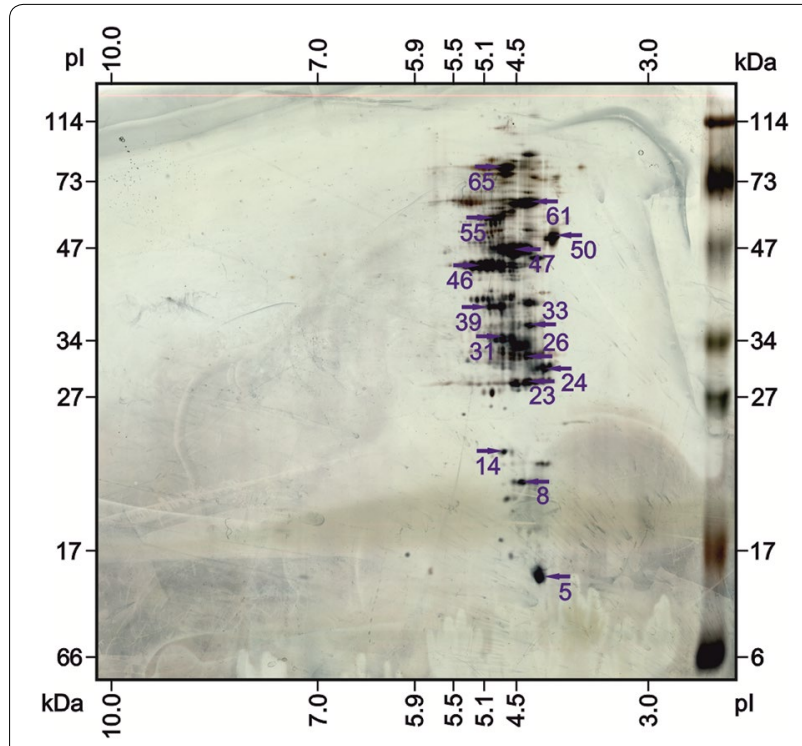

Fig. 5 The Protein profiles of spots chosen for MALDI-TOF identification obtained from phages specific for M. haemolytica strains
Analysis of selected common protein spots n 2D electrophoresis (Fig. 5) using MALDI-TOF mass spectrometry showed a significant percentage of similarity (more than $70 \%$ ) in the case of two protein spots with molecular weights of 15.02 and $15.067 \mathrm{kDa}$. These protein sequences showed high similarity to Late genes activator $\mathrm{OS}=$ Bacillus phage $\mathrm{B} 103$ and $\mathrm{OS}=$ Bacillus phage Nf. One of the spots analysed $(17.028 \mathrm{kDa})$ was more than $40 \%$ similar to Gene 29 protein OS=Mycobacterium phage $\mathrm{D} 29$. The remaining spots showed a similarity percentage of less than $40 \%$. However, spot number 47 (MW 54.006) was identified as the uncharacterized protein 017L OS = Mannheimia haemolytica Mu-like phage (Table 1). All information contained in reports from the database, relevant active pdf files with the results of searches for selected proteins along with matching sequences to reference proteins from databases (SwissProt) have been attached as Additional file 1.

\section{Discussion}

Analysis of the phage isolates induced from M. haemolytica showed slight variation in protein profiles in SDSPAGE electrophoresis and significant differences in protein profiles in $2 \mathrm{D}$ electrophoresis. This is interesting

Table 1 The MALDI-TOF identification of selected common spots obtained from various phages specific for $M$. haemolytica strains

\begin{tabular}{|c|c|c|c|c|c|c|c|}
\hline Spot label & Protein & UniProt & Score & $\begin{array}{l}\text { Protein } \\
\text { sequence } \\
\text { coverage }(\%)\end{array}$ & $\begin{array}{l}\text { Mass } \\
\text { values } \\
\text { matched: }\end{array}$ & MW (kDa) & pl \\
\hline 5 & $\begin{array}{l}\text { Gag-Pol polyprotein OS = Human immunodeficiency virus type } \\
1 \text { group M subtype J (isolate SE9280) }\end{array}$ & POL_HV1S2 & 60 & 21 & 23 & 163,169 & 8.90 \\
\hline 8 & $\begin{array}{l}\text { Probable tape measure protein OS= Pseudomonas phage } \\
\text { PAJU2 }\end{array}$ & TMP_BPPAJ & 81 & 17 & 13 & 99,205 & 5.14 \\
\hline 14 & $\begin{array}{l}\text { Large structural phosphoprotein OS = Human herpesvirus } 7 \\
\quad(\text { strain } \mathrm{J})\end{array}$ & P100_HHV7 J & 66 & 16 & 9 & 86,698 & 6.37 \\
\hline \multicolumn{8}{|l|}{19} \\
\hline 23 & Major inner protein P1 OS=Pseudomonas phage phi6 & P1_BPPH6 & 66 & 13 & 9 & 85,105 & 6.34 \\
\hline 24 & Late genes activator OS= Bacillus phage B103 & VG4_BPB03 & 72 & 72 & 6 & 15,020 & 9.66 \\
\hline 26 & Late genes activator OS= Bacillus phage $\mathrm{Nf}$ & VG4_BPNF & 59 & 75 & 5 & 15,067 & 9.75 \\
\hline 31 & $\begin{array}{l}\text { Gag-Pol polyprotein OS = Human immunodeficiency virus type } \\
1 \text { group M subtype J (isolate SE9280) }\end{array}$ & $\mathrm{POL} / \mathrm{HV} 1 \mathrm{~S} 2$ & 114 & 19 & 20 & 163,169 & 8.90 \\
\hline 33 & $\begin{array}{l}\text { Defense against restriction protein } \mathrm{B} O \mathrm{~S}=\text { Enterobacteria } \\
\text { phage } \mathrm{P} 1\end{array}$ & DARB_BPP1 & 161 & 13 & 30 & 251,899 & 5.41 \\
\hline 39 & RNA replication protein OS $=$ Shallot virus $X$ & RDRP_SHVX & 83 & 10 & 15 & 195,947 & 8.56 \\
\hline 46 & RNA replication protein $O S=$ Shallot virus $X$ & RDRP_SHVX & 115 & 14 & 20 & 195,947 & 8.56 \\
\hline 47 & $\begin{array}{l}\text { Uncharacterized protein } 017 \mathrm{~L} \text { OS = Mannheimia haemolytica } \\
\text { Mu like phage }\end{array}$ & 017L_FRG3G & 59 & 31 & 18 & 54,006 & 6.15 \\
\hline 50 & $\begin{array}{l}\text { Putative structural protein VP3 OS = Lymantria dispar cypovirus } \\
1 \text { (isolate Rao) }\end{array}$ & VP3_LDCPR & 137 & 18 & 19 & 140,252 & 5.35 \\
\hline 55 & Antitoxin phd OS = Enterobacteria phage P1 & PHD_BPP1 & 77 & 35 & 5 & 8128 & 5.08 \\
\hline 61 & $\begin{array}{l}\text { DNA-directed DNA polymerase OS = Vibrio phage KVP40 (iso- } \\
\text { late Vibrio parahaemolyticus/Japan/Matsuzaki/1991) }\end{array}$ & DPOL_BPKVM & 93 & 22 & 17 & 98,921 & 5.59 \\
\hline 65 & Gene 29 protein OS = Mycobacterium phage D29 & VG29_BPMD2 & 72 & 41 & 6 & 17,028 & 5.61 \\
\hline
\end{tabular}


in that the bacteriophages obtained were all identified as belonging to the family Myoviridae on the basis of morphological analysis under an electron microscope.

As shown in a study by Jarvis et al. (1993), analysis of the protein profiles of phages in SDS-PAGE electrophoresis can reveal what properties (e.g. morphology, protein or DNA composition, genome structure, or restriction endonuclease pattern) are more conserved than others and which will evolve depending on the type of bacteria they replicate on.

In the present study, in the case of the protein profiles observed in SDS-PAGE electrophoresis, very similar profiles were obtained for 5 phages induced from $M$. haemolytica strains of serotypes A1, A2, A3, A5, A6 and $A 7$, while in the case of one $(\$ 25)$ the image differed slightly and showed significant similarity to phage PHL2 (BAA410), which confirms earlier research UrbanChmiel et al. (2015). It should be emphasized here that individual protein fractions were localized within a molecular weight range from 25.8 to $73.13 \mathrm{kDa}$. The results of the study confirm those obtained by other researchers, who observed certain similarities between phages isolated from different bacteria, often belonging to different species or genera. For example, Jarvis et al. (1993) found that despite the fact that their analysis was conducted on phages obtained from different bacteriaBacillus subtilis, B. thuringiensis, Enterococcus sp., Lactobacillus plantarum and Staph. aureus-belonging to the same family Myoviridae, the protein profiles obtained in SDS-PAGE electrophoresis were very similar. However, they were not identical and were characterized by the occurrence of 5-7 protein fractions localized in the molecular weight range from 46 to $69 \mathrm{kDa}$. In a study by Lavigne et al. (2006), using the T7-like Pseudomonas bacteriophage $\mathrm{pKMV}, 12$ virion proteins were identified, of which six had previously been identified as structural proteins due to the similarity between structural protein sequences and known phage proteins. Five additional proteins, whose sequences showed little similarity to known phage proteins, were classified as structural proteins. In another study, by Zhang et al. (2006), no differences were observed in the electrophoresis protein profiles of phages specific for Lactobacillus fermentum, and the number of protein fractions in the molecular weight range from 25.8 to $79.6 \mathrm{kDa}$ varied from 5 to 7 . The authors state that all the phages belonged to the family Siphoviridae and had lysogenic properties, and the restriction profiles obtained in restriction analysis were identical and did not allow for a comprehensive characterization. Similarly, in a study by Ngangbam and Devi (2012), SDS-PAGE electrophoretic separation of phages specific for Salmonella strains revealed 5 fractions, with molecular weights of $56,52,48$, and $33 \mathrm{kDa}$. As the authors point out, similar results were obtained as early as 1978 by other researchers in the case of phages T2 and T384 specific for $E$ coli strains (Hantke 1978).

The authors of another study (Radhakrishnan and Ananthasubramanian 2012) conducted on phages specific for Pseudomonas fluorescens, suggest that the molecular weights of the major proteins do not vary among phage lysates specific to the same bacterial strains.

In the protein fractions obtained in the present study we also observed the occurrence of main fractions with a molecular weight of 34.8 or $39.8 \mathrm{kDa}$, and the number of bands obtained ranged from 5 to 7 fractions, which confirms results obtained by other authors (Zhang et al. 2006; Lavigne et al. 2006; Ceyssens et al. 2008).

In the case of the protein profiles obtained in $2 \mathrm{D}$ electrophoresis a varied number of spots was observed, corresponding to individual proteins, in numbers ranging from 15 to $>130$. In a study by Roberts et al. (2004), 15 main proteins were obtained in $2 \mathrm{D}$ analysis of protein profiles of coliphage T1. According to the authors, the range of occurrence of proteins depends on the size, spatial structure and morphology of the phages.

Analysis of the 2D electrophoresis profiles of the phages revealed the presence of proteins common to phages specific for other bacteria, such as Bacillus, Mycobacterium or Pseudomonas.

According to Maxwell and Frappier (2007), identification of the main proteins of the capsid and tail of phages, which are available, for example, in a genome database, may enable morphogenetic annotation of the region. Therefore it can be concluded that two-dimensional analysis of protein profiles in conjunction with mass spectrometry analysis is a more precise tool for comprehensive characterization of bacteriophages, particularly when restriction analysis is inadequate. As wrote Das et al. (2014) using of a combination of molecular biology methods both with conventional microbiological technics is necessary to obtain a better understanding of microbial diversity.

To sum up the results indicate that although the bacteriophages obtained mostly belong to the same family, Myoviridae, and were induced on the same species of bacteria, there are differences in their morphological structure and protein profiles, which may influence their virulence, stability and range of lytic activity. Moreover, the profiles obtained exhibit a certain similarity to other phage proteins induced for other bacteria, which was confirmed in the MALDI-TOF analysis and in other studies. We can conclude from the results that the methods used in the present study could be very helpful in 
differentiating the protein profiles of phages, even those belonging to the same family.

However the presented in this study results were the preliminary study and will be still continued, and after submitting patent applications for the obtained "new" phages, their full amino acid sequences will be made available in GenBank.

\section{Additional file}

Additional file 1. Mascot search results( POL_HV1S2): the aminosequences of the obtained bacteriophages proteins.

\section{Abbreviations}

2D electrophoresis: two-dimensional gel electrophoresis; ATCC: American Type Culture Collection; BHIB: brain heart infusion broth; BHIA: brain heart infusion agar; BRDC: bovine respiratory disease complex; DTT: dithiothreitol; SDS PAGE: sodium dodecyl sulfate.

\section{Authors' contributions}

RUC - the concept of the study, main coordinator of the study, participation in laboratory work (isolation of bacteriophages, isolation of M. haemolytica strains, electrophoresis analysis) and preparation of the manuscript (writing, statistical analysis), AW- participation in preparation of the manuscript, concept of the study, JW - participation in the 2D electrophoresis analysis, MALDI-TOF analysis, AP — participation in SDS-PAGE electrophoresis, AN-participation in isolation of $M$. haemolytica bacteriophages, MD - participation in protein profile analysis and preparation of the manuscript, DS—-participation in bacteriophage isolation, MA - participation in bacteriophage isolation. All authors read and approved the final manuscript.

\section{Author details}

${ }^{1}$ Sub-department of Veterinary Prevention and Avian Diseases, Institute of Biological Bases of Animal Diseases, Faculty of Veterinary Medicine, University of Life Sciences, 20-033 Lublin, Poland. ${ }^{2}$ Department of Biochemistry, Faculty Veterinary Medicine, University of Life Sciences, 20-033 Lublin, Poland.

${ }^{3}$ Faculty of Veterinary Medicine, University of Al Muthanna, Samawah, Iraq.

\section{Acknowledgements}

The authors would like to thank Professor Schimmel from the Bundesinstitut Fürgesundheitlichen Verbraucherschutz und Veterinärmedizin, Jena for supplying the M. haemolytica reference strains.

\section{Competing interests}

The authors declare that they have no competing interests.

\section{Availability of data and materials}

The full genomic sequence of $\mathrm{PH} 2 \mathrm{M}$. haemolytica phage was presented in publication of Highlander et al. (2006). A similar GenBank accession numbers of $M$. haemolytica reference phages have been available also in references Niu et al. (2015)

\section{Consent for publication}

"Not applicable".

\section{Ethics approval and consent to participate}

All authors contributed during experimental work and scientific writing of this manuscript.

The authors obtained the consent of the Second Local Ethics Committee for Animal Experiments in Lublin (Approval Number 39/2009, 09 June 2009).

This article does not contain any studies with human participants performed by any of the authors.
Funding

"Not applicable".

\section{Publisher's Note}

Springer Nature remains neutral with regard to jurisdictional claims in published maps and institutional affiliations.

Received: 13 November 2017 Accepted: 14 June 2018

Published online: 19 June 2018

\section{References}

Barrangou R, Yoon SS, Breidt F, Fleming HP, Klaenhammer TR (2002) Identification and characterization of Leuconostoc fallax strains isolated from industrial sauerkraut fermentation. Appl Environ Microbiol 68:2877-2884

Bovet PJ, Jeanjean S, Vieu JV, Dijkshoorn L (1990) Species, biotype, and bacteriophage type determinations compared with protein profiles for typing Acinetobacter strains. J Clin Microbiol 28:170-176

Ceyssens PJ, Mesyanzhinov V, Sykilinda N, Briers Y, Roucourt B, Lavigne R, Robben J, Domashin A, Miroshnikov K, Volckaert G, Hertveldt K (2008) The genome and structural proteome of YuA, a new Pseudomonas aeruginosa phage resembling M6. J Bacteriol 190:1429-1435

Das S, Dash HR, Mangwani N, Chakraborty J, Kumari S (2014) Understanding molecular identification and polyphasic taxonomic approaches for genetic relatedness and phylogenetic relationships of microorganisms. J Microbiol Meth 103:80-100

Davies RL, Lee I (2006) Diversity of temperate bacteriophages induced in bovine and ovine Mannheimia hemolyica isolates and identification of a new P2-like phage. FEMS Microbiol Lett 260:162-170

Elshayeb AA, Yagoub SO, Yousif AS, Abedalkareem EA, Hag SME, Elagib AA (2011) Identification of protein profiles of Escherichia coli, Staphylococcus aureus and their corresponding phages. Am J Biotechnol Mol Sci $1: 39-44$

Hantke K (1978) Major outer membrane protein of Escherichia coli K12 serve as receptors for the phage T2 (protein 1a) and 434 (protein 1b). Mol Gen Genet 164:131-135

Highlander SK, Weissenberger S, Alvarez LE, Weinstock GM, Berget PB (2006) Complete nucleotide sequence of a P2 family lysogenic bacteriophage, QMhaA1-PHL101, from Mannheimia haemolytica serotype A1. Virology 350:79-89

HuffWE, Huff GR, Rath NC, Balog JM, Xie H, Moore PA, Donoghue AM (2002) Prevention of Escherichia coli respiratory infection in broiler chickens with bacteriophage (SPRO2). Poultry Sci 81:437-441

Jarvis AW, Collins LJ, Ackermann HW (1993) A study of five bacteriophages of the Myoviridae family which replicate on different gram-positive bacteria. Arch Virol 133:75-84

Kutateladze M, Adamia R (2010) Bacteriophages as potential new therapeutics to replace or supplement antibiotics. Trends Biotechnol 28:591-595

Laemmli UK (1970) Cleavage of structural proteins during the assembly of the head of bacteriophage T 4. Nature 227:680-685

Lavigne R, Noben JP, Hertveldt K, Ceyssens PJ, Briers Y, Dumont D, Roucourt B, Krylov VN, Mesyanzhinov WV, Robben J, Volckaert G (2006) The structural proteome of Pseudomonas aeruginosa bacteriophage $\varphi \mathrm{KMV}$. Microbiology 152:529-534

Leverentz B, Conway WS, Janisiewicz W, Camp MJ (2004) Optimizing concentration and timing of a phage spray application to reduce Listeria monocytogenes on honeydew melon tissue. J Food Protect 67:1682-1686

Maxwell KL, Frappier L (2007) Viral proteomics. Microbiol Mol Biol Rev 71:398-411

Ngangbam AK, Devi NBL (2012) Molecular characterization of Salmonella bacteriophages isolated from natural environment and its potential role in phage therapy. J Agr Vet Sci 1:7-11

Ngwai YB, Kozo O, Yasuki O, Adachi Y (2005) Analysis of the protein profiles of the antibiotic resistant Salmonella typhimurium definitive phage type (dt) 104. African J Biotechnol 4:727-737 
Niu YD, Cook SR, Wang J, Klima CL, Hsu Y, Kropinski AM, Turner D, McAllister TA (2015) Comparative analysis of multiple inducible phages from Mannheimia haemolytica. BMC Microbiol 15:175

O'Farrell PH (1975) High resolution two-dimensional electrophoresis of proteins. J Biol Chem 250:4007-4021

Radhakrishnan A, Ananthasubramanian M (2012) Characterization and lytic activity of Pseudomonas fluorescens phages from sewage. Brazilian J Microbiol 43:356-362

Roberts MD, Martin NL, Kropinski AM (2004) The genome and proteome of coliphage T1. Virology 318:245-266

Urban-Chmiel R, Wernicki A, Stęgierska D, Dec M, Dudzic A, Puchalski A (2015) Isolation and characterization of lytic properties of bacteriophages specific for M. haemolytica strains. PLoS ONE 10(1-11):e0140140. https:// doi.org/10.1371/journal.pone.0140140
Webster J, Oxley D (2005) Peptide mass fingerprinting: protein identification using MALDI-TOF mass spectrometry. Method Mol Biol 310:227-240

Xie H, Zhuang XZ, Kong JC, Ma G, Zhang H (2005) Bacteriophage Esc-A is an efficient therapy for Escherichia coli 3-1 caused diarrhea in chickens. J Gen Appl Microbiol 51:159-163

Zhang X, Kong J, Qu Y (2006) Isolation and characterization of a Lactobacillus fermentum temperate bacteriophage from Chinese yogurt. J Appl Microbiol 101:857-863

Zimmer M, Scherer S, Loessner MJ (2002) Genomic Analysis of Clostridium perfringens Bacteriophage $\$ 3626$, which integrates into guaA and possibly affects sporulation. J Bacteriol 184:4359-4368

\section{Submit your manuscript to a SpringerOpen ${ }^{\odot}$ journal and benefit from:}

- Convenient online submission

- Rigorous peer review

- Open access: articles freely available online

- High visibility within the field

- Retaining the copyright to your article

Submit your next manuscript at $\boldsymbol{\text { springeropen.com }}$ 